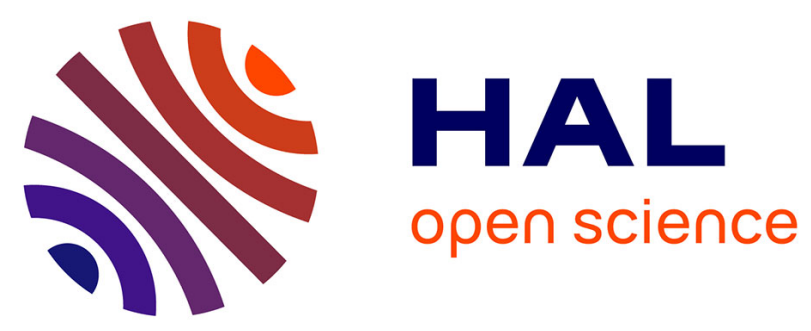

\title{
Fossil beetles as possible evidence for transhumance during the middle and late Holocene in the high mountains of Talysch (Talesh) in NW Iran?
}

Philippe Ponel, Valérie Andrieu-Ponel, Morteza Djamali, Hamid Lahijani, Michelle Leydet, Marjan Mashkour

\section{To cite this version:}

Philippe Ponel, Valérie Andrieu-Ponel, Morteza Djamali, Hamid Lahijani, Michelle Leydet, et al.. Fossil beetles as possible evidence for transhumance during the middle and late Holocene in the high mountains of Talysch (Talesh) in NW Iran?. Environmental Archaeology, 2013, 18 (3), pp.201-210. 10.1179/1749631413y.0000000007 . hal-01968861

\section{HAL Id: hal-01968861 \\ https://hal-amu.archives-ouvertes.fr/hal-01968861}

Submitted on 3 Jan 2019

HAL is a multi-disciplinary open access archive for the deposit and dissemination of scientific research documents, whether they are published or not. The documents may come from teaching and research institutions in France or abroad, or from public or private research centers.
L'archive ouverte pluridisciplinaire HAL, est destinée au dépôt et à la diffusion de documents scientifiques de niveau recherche, publiés ou non, émanant des établissements d'enseignement et de recherche français ou étrangers, des laboratoires publics ou privés. 


\title{
Fossil beetles as possible evidence for transhumance during the middle and late Holocene in the high mountains of Talysch (Talesh) in NW Iran?
}

\author{
Philippe Ponel ${ }^{1}$, Valérie Andrieu-Ponel ${ }^{1}$, Morteza Djamali ${ }^{1}$, Hamid Lahijani ${ }^{2}$, \\ Michelle Leydet ${ }^{1}$, Marjan Mashkour ${ }^{3}$
}

${ }^{1}$ IMBE-CNRS-IRD-UAPV, Aix-Marseille Université, Technopôle de l'Environnement Arbois-Méditerranée, BP 80,
F-13545 Aix-en-Provence cedex 04, France, ${ }^{2}$ Iranian National Institute for Oceanography (INIO), No. 9 Etemad
Zadeh Street, West Fatemi Ave., 14155-4781 Tehran, Iran, ${ }^{3}$ Laboratoire d'Archéozoologie et Archéobotanique,
UMR 7209 CNRS, Département Ecologie et Gestion de la Biodiversité, Muséum National d'Histoire Naturelle
(MNHN), 55 rue Buffon, 75005 Paris, France

A short sediment core $(300 \mathrm{~cm}$ ) was retrieved from a peaty deposit in the northeastern corner of Lake Neor in NW Iran yielding a 6500-year-old sequence relatively rich in pollen and beetle remains. Beetle assemblages contained a significant amount of coprophagous and coprophilous species all along the core. Pollen spectra suggest an open steppe landscape typical of the modern Irano-Turanian highlands with pollen indicators of agro-pastoral activities and also the proximity of the mesic temperate Hyrcanian forest to the east. Together, insect and pollen evidence, in agreement with the archaeological evidence for NW Iran, suggest that pastoralism was practised in the high elevation surroundings of Neor in Talysch Mountains at least since ca. 6500 years ago. This preliminary study highlights the strong potential of palaeoentomological investigations in furthering our understanding of the history of pastoralism in the Middle East.

Keywords: Coleoptera, Pollen, Holocene, Iran, Neor lake, Pastoralism

\section{Introduction}

Recent high-resolution palaeoecological investigations of lake and peat deposits have been very informative in detecting high-frequency climatic events, reconstructing human impact on ecosystems, and understanding socio-economic changes driven by climatic and historical events in the Middle East (Neumann et al. 2007; Ramezani et al. 2008; Djamali et al. 2009b). In Lake Maharlou in southern Zagros, significant human activity is implicated in causing a large-scale deforestation event, leading to an almost total destruction of Pistacia-Amygdalus steppe forest contemporaneous with the Achaemenid period (Djamali et al. 2008). However, despite the importance of pollen analysis in reconstructing past vegetation change in relation to climate change and human activities, and

Correspondence to: Philippe Ponel, IMBE-CNRS-IRD-UAPV, Aix-Marseille Université, Technopôle de l'Environnement Arbois-Méditerranée, BP 80, F-13545 Aix-en-Provence cedex 04, France.

Email: philippe.ponel@imbe.fr the recent development of studies aiming to improve the interpretation of fossil pollen assemblages in Iran (Djamali et al. 2009a), it seems that the identification and classification of anthropogenic indicator pollen taxa is less clear or more poorly known in the Middle East and even Central Asia compared to Europe and the Mediterranean region (e.g. Djamali et al. 2008; Miehe et al. 2009). However, at Lake Almalou, in the first palaeoentomological environment reconstruction in the Middle East, Djamali et al. (2009b) considered the discovery of dung beetle remains in layers corresponding to the Achaemenid period (2450-2220 cal. yr BP) to be possible evidence for intensive agro-pastoral activity in this region.

In the present study, we use fossil beetle analysis as a tool to complement pollen for finding traces of pastoralism in the Lake Neor region in NW Iran. The area has several interesting ecological and archaeological characteristics. First, it is located at the limit of two contrasting climatic systems: the temperate humid 
South Caspian climate in the east and semi-arid continental climate of Irano-Armenian plateau. Second, it lies at the extreme eastern limit of the IranoArmenian montane steppes and is very close to the Hyrcanian forest (South Caspian forest) in the east. Third, the area still hosts nomadic tribes, and was densely populated in the past as shown in the archaeological records (Fahimi 2004; Kazua and Fahimi 2005; Khalatbari 2004; Mashkour 2005; Nokandeh 2005). These features suggest a high potential for the site to provide evidence of the past vegetation, climate and the history of agro-pastoralism.

The two main objectives of this study are therefore

(i) to reconstruct the mid- to late-Holocene palaeoenvironment of Lake Neor region using both beetle and pollen analyses;

(ii) to evaluate the potential of fossil beetles for understanding the history of pastoralism in a typical Middle Eastern mountainous region.

\section{Physical Setting}

Lake Neor (also Neur) is a freshwater lake of tectonic origin located in a high altitude intermontane closed basin (ca. $2480 \mathrm{~m}$ a.s.1.) in the Talesh Mountains (also Talysch) which form a high continuous range separating the Caspian Sea basin in the east from the high plateau of Azerbaijan in the west (Fig. 1). The lake is about $4000 \mathrm{~m}$ long and $1000 \mathrm{~m}$ wide. Mean water depth is ca. $2 \mathrm{~m}$ with a maximum of $5.5 \mathrm{~m}$ in the SE corner (Nejadsattari 1978). In several places where springs enter the lake, peat bogs have been encroaching towards the central part of the lake (see letter $\mathrm{P}$ in Fig. 1).

\section{Flora and Vegetation}

Lake Neor region is located about $10 \mathrm{~km}$ to the west of the Hyrcanian forest which borders the southern plains of the Caspian Sea and the northern foothills of the Alborz Mountains. This forest is located in the extreme southeastern extension of the Euro-Siberian floristic region which receives moisture from Mediterranean, North Atlantic, Black Sea and particularly the Caspian Sea nearly all the year round. The higher altitude vegetation belts of this forest in Assalem (45 km to the SE of the lake) consist of a forest dominated by Fagus orientalis Vaccinium arctostaphylos - Ilex aquifolium communities (1200-1800 m), a strongly disturbed and almost completely destroyed belt (1800-2100 m) potentially occupied by Fagus orientalis - Carpinus orientalis mixed forest, and Carpinus orientalis open scrubs at 2100-2600 m (Assadollahi 1980). More to the west, the high range of Talesh blocks the humid air masses of the Caspian Sea and deprives the western slopes of this mountain range of moisture
(Fig. 1). This leads to the development of typical Irano-Turanian montane steppes with occasional intruded plants of Euro-Siberian origin. In a recently published map representing the main vegetation types of Ardebil-Astara region (Sharifi 2009), the western slopes of mountain ranges in the immediate vicinity of Lake Neor are covered by an IranoTuranian thorn-cushion montane steppe vegetation dominated by Onobrychis cornuta - Astragalus sp. Agropyron communities. The eastern slopes are, however, dominated by Festuca heterophyllum Trifolium montana communities. The vegetation around Lake Neor is under strong grazing activity as evidenced by the presence of many ruderal plants including Rumex, Plantago etc.

The most important plants growing in peaty soil on the lake banks can be listed as: Cyperaceae, Ranunculus sp., Butomus umbellatus, mosses (Amblystegiaceae cf Drepanocladus sp.), a liverwort species (Riccia cf cavernosa). While Riccia almost completely disappears before being incorporated in the peat, the moss species seems to be an important peat-forming taxon in the absence of Sphagnum spp. in the Iranian flora.

\section{Material and Methods Coring}

Coring was carried out with a Russian-type corer. A $300-\mathrm{cm}$ sedimentary sequence was extracted from a peaty area located in the North-East part of the lake (Fig. 1). This place was chosen for beetle analysis because it was located close to a small tributary, able to transport and deposit dead insects from a wider catchment basin. The upper $50 \mathrm{~cm}$ of the core was made up of a network of helophytic plant roots, fluid sediment and water; it was not recovered.

\section{Lithology and Chronology}

The lower parts of the core $(270-300 \mathrm{~cm})$ were lacustrine organic muds, overlain by a peat deposit from around $230 \mathrm{~cm}$ upwards. Three radiocarbon dates were performed on bulk sediment (Table 1). The age calibrations were done in Calib 5.0.2 software (Stuiver et al. 1998) and the age-depth model was constructed in the software package CLAM (Blaauw 2010) run in the software R (R Development Core Team 2010).

\section{Sample Processing \\ Pollen}

Pollen extraction was carried out following Moore et al. (1994) and using successive treatments with $\mathrm{HCl}, \mathrm{HF}$ and acetolysis. For pollen identifications, we used the pollen reference collection of IMBE including reference slides of Iranian flora as well as the pollen atlases of Europe and N. Africa (Reille 1992, 1995, 1998; Beug 2004) and also pollen 


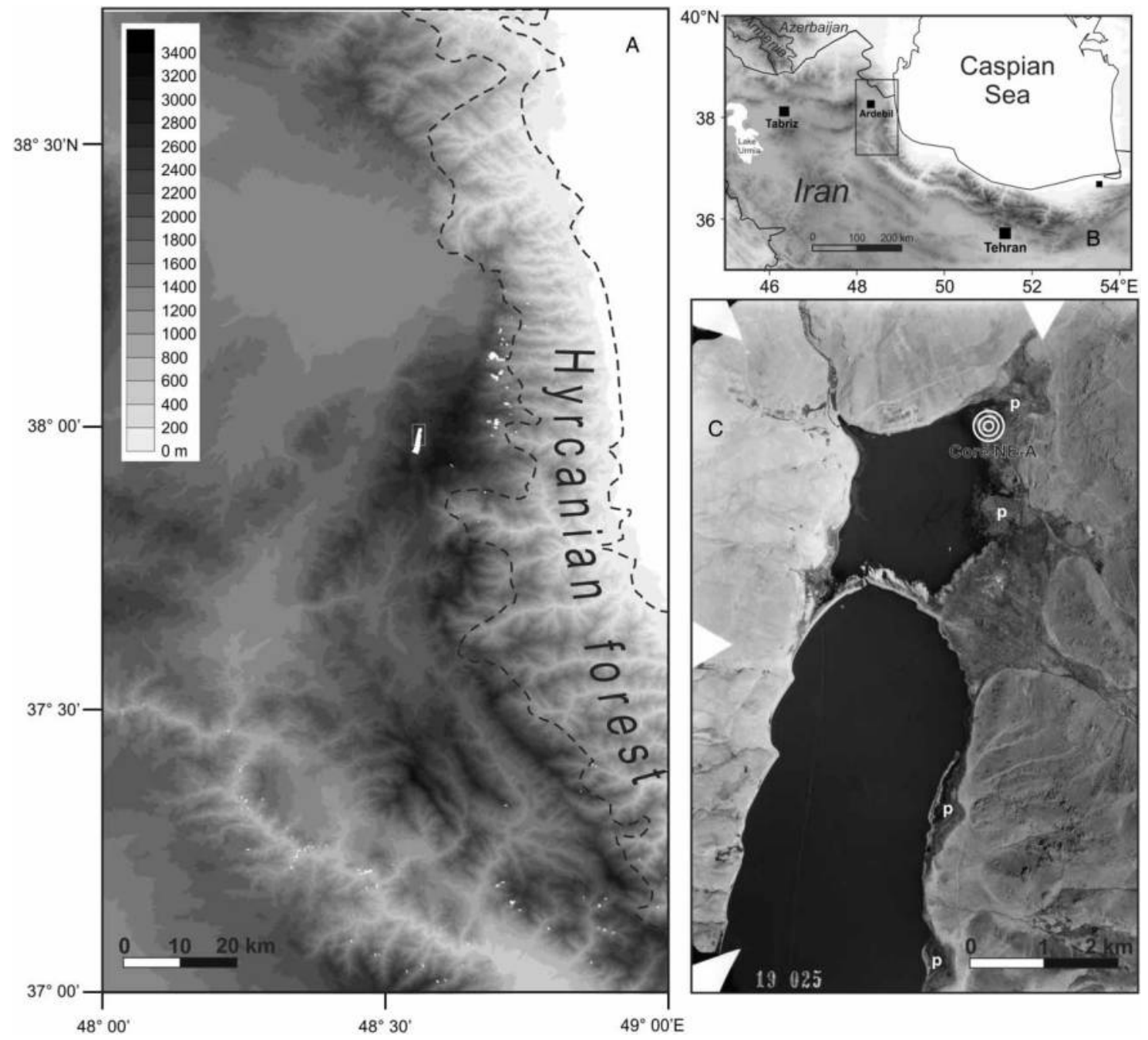

Figure 1 Location map of Lake Neor in NW Iran (A and B) and the coring site in NW of the lake (C). P marks the positions of peat bogs and concentric circles mark the coring site.

morphological data in van Zeist and Bottema (1977). A total of 20 samples were analysed. New samples will be analysed in the near future to improve the time resolution. Hygrophilous and aquatic plants (in particular Cyperaceae, which are over-represented) as well as non-pollen palynomorphs (NPPs), among them fungal spores, algal cysts and animal microremains, have been excluded from the pollen sum (PS).

\section{Beetles}

The sedimentary profile was cut into 25 samples for insect analysis. Each sample was $10-\mathrm{cm}$ thick and ca. $140 \mathrm{~cm}^{3}$ in volume. The 25 insect samples numbered from 1 (bottom) to 25 (top of the sequence) span continuously the entire sedimentary profile $(250 \mathrm{~cm})$, from the surface to the rocky bottom of the lake. The fossils were extracted using the method recommended by Coope (1986), and identifications were made by direct comparison with specimens from a modern reference collection. Ecological interpretation and biogeographical data are derived from Koch (1989a, 1989b, 1992), Böhme (2005), and Löbl and Smetana (2003-2010).

\section{Results}

\section{Pollen}

The mean PS is 365 (NPPs excluded) and the total of taxa identified (NPPs included) is 147. The pollen

Table 1 Radiocarbon ages of core Neor NE-A*

\begin{tabular}{lccccr}
\hline Sample No. & Depth $(\mathbf{c m})$ & Lab code & ${ }^{14}$ C age (yr BP) & Calibrated age (cal yr BP) & Material dated \\
\hline Neor NE-A1 & $64-65$ & Poz-29447 & $110.79 \pm 0.36 \mathrm{pMC}$ & $90 \pm 29$ & Peat \\
Neor NE-A2 & $150-151$ & Poz-29448 & $2780 \pm 30 \mathrm{BP}$ & $2872 \pm 80$ & Peat \\
Neor NE-A3 & $282-283$ & Poz-29449 & $5410 \pm 35 \mathrm{BP}$ & $6235 \pm 57$ & Gytja \\
\hline
\end{tabular}

${ }^{*}$ Calibrated dates are reported as the mean of the $2 \sigma$ ranges with highest probability. Age-depth model corresponding to these ages are depicted in Fig. 2. 
concentration is low as is often the case in pollen spectra coming from peat deposits of arid environments (Djamali 2008). The lower $20 \mathrm{~cm}$ of the core was depleted of pollen as well as the sample situated at $113 \mathrm{~cm}$ that was mainly made up of charcoal particles, indicating important fire event(s). The flora identified in the pollen record is typical of NW Iran with a mixture of both Hyrcanian phytogeographical zone (nowadays occupying the southern edges of Caspian Sea) and the Irano-Turanian region of the Azerbaijan plateau. Many taxa indicators of livestock breeding or associated with cultural activities were recognised in the whole of the pollen record testifying to early anthropogenic activities in the Talesh mountains. The description of the vegetation history recorded at Lake Neor relies on the simplified pollen diagram presented in Fig. 2 and is particularly focused on the impact of human activities on the environment.

The mean relative frequencies of the tree pollen remain very low $(<20 \%$ of the PS) throughout the sequence. The Hyrcanian forest is represented by low values of Fagus (2\%), Carpinus (2\%), Acer and median values of deciduous Quercus (10\%). Usually, the pollen of Fagus is not a long distance transported pollen but the presence of in situ Fagus forest cannot occur over $2000 \mathrm{~m}$ above sea level and it is extremely probable that this pollen has come from areas of lower altitudes, bordering the southern coast of the
Caspian Sea. The landscape around the lake was mainly occupied by grass steppes with Poaceae (24.8\%), Artemisia (23\%), Chenopodiaceae (3.6\%) and several Compositae (Anthemis, Aster, various species of Centaurea, Cirsium, Cichorioideae, Cousinia, Echinops, Evax). Fabaceae observed at Neor are diverse and comprise (ascending order): Ononis-type, Hedysarum-type, Lotus-type, Ulex, Lupinus-type; some of them could have been cultivated (Lupinus) to feed regional human populations or used as fodder plants (Hedysarum and Lupinus) for the livestock. The presence of crop plants is noted from the bottom of the core and comprises undifferentiated Cerealia and Secale associated with arable weeds (Turgenia latifolia, Centaurea cyanus, C. solstitialis and Polygonum aviculare), and fruit trees (Prunus, Juglans, Olea). The regular pollen occurrence of nitrophilous plants and ruderals (Plantago lanceolata, Cichorioideae, Polygonum aviculare, Urtica) seems to indicate that farmers reared livestock in the vicinity of the site. Frequent visits to the edge of the lake by mammal herds can also explain the high values of fungal spores, some of which are dependent on mammal dung.

The depositional environment changes from the bottom to the top, passing from a lacustrine stage to a terrestrial environment when a peat bog forms (Fig. 3). These two phases are recorded in the pollen spectra by the presence of many aquatic or

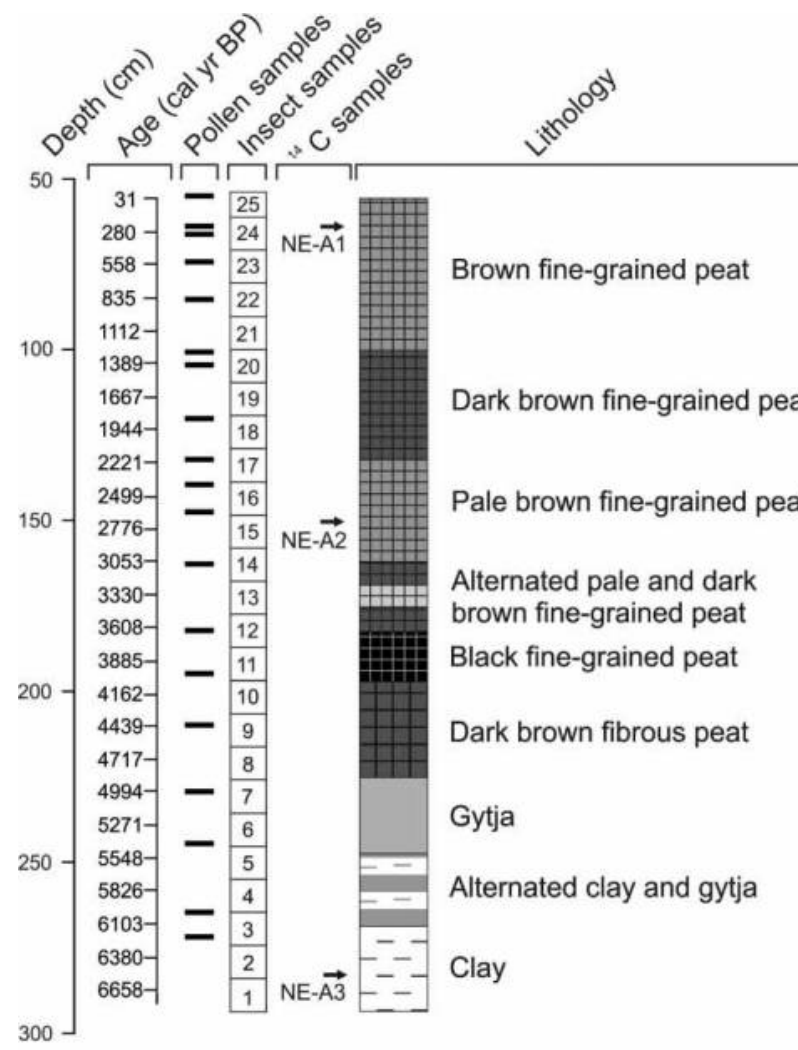

\section{Age-depth model}

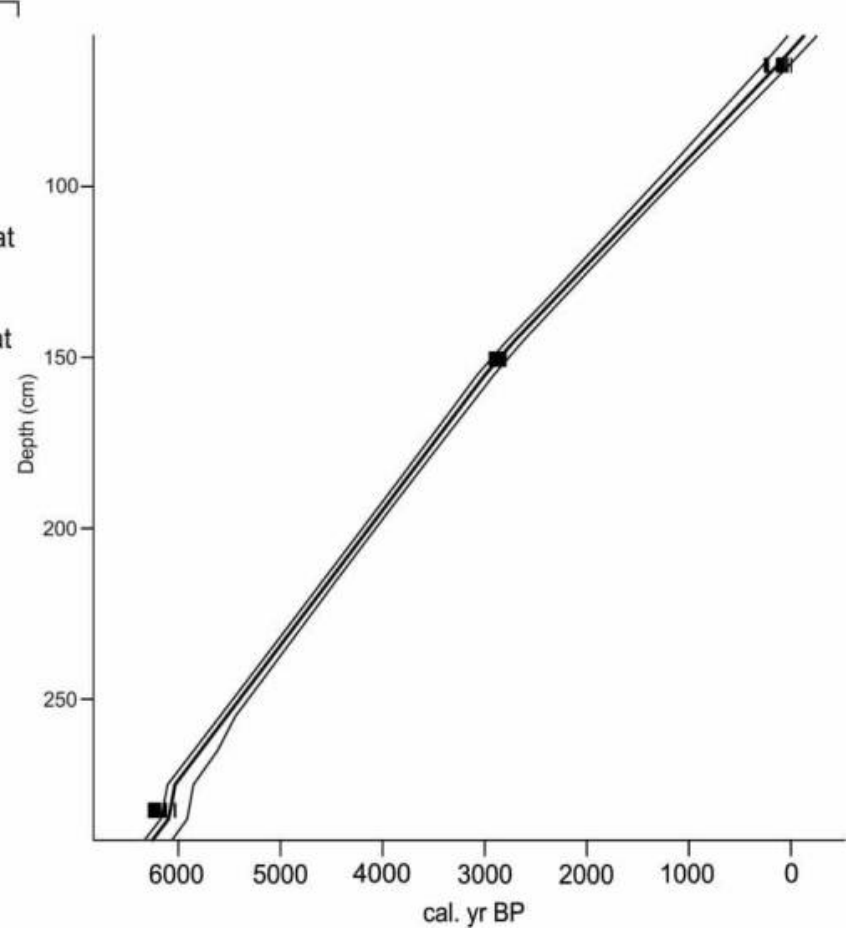

Figure 2 Age-depth model and stratigraphy of core Neor NE-A. 


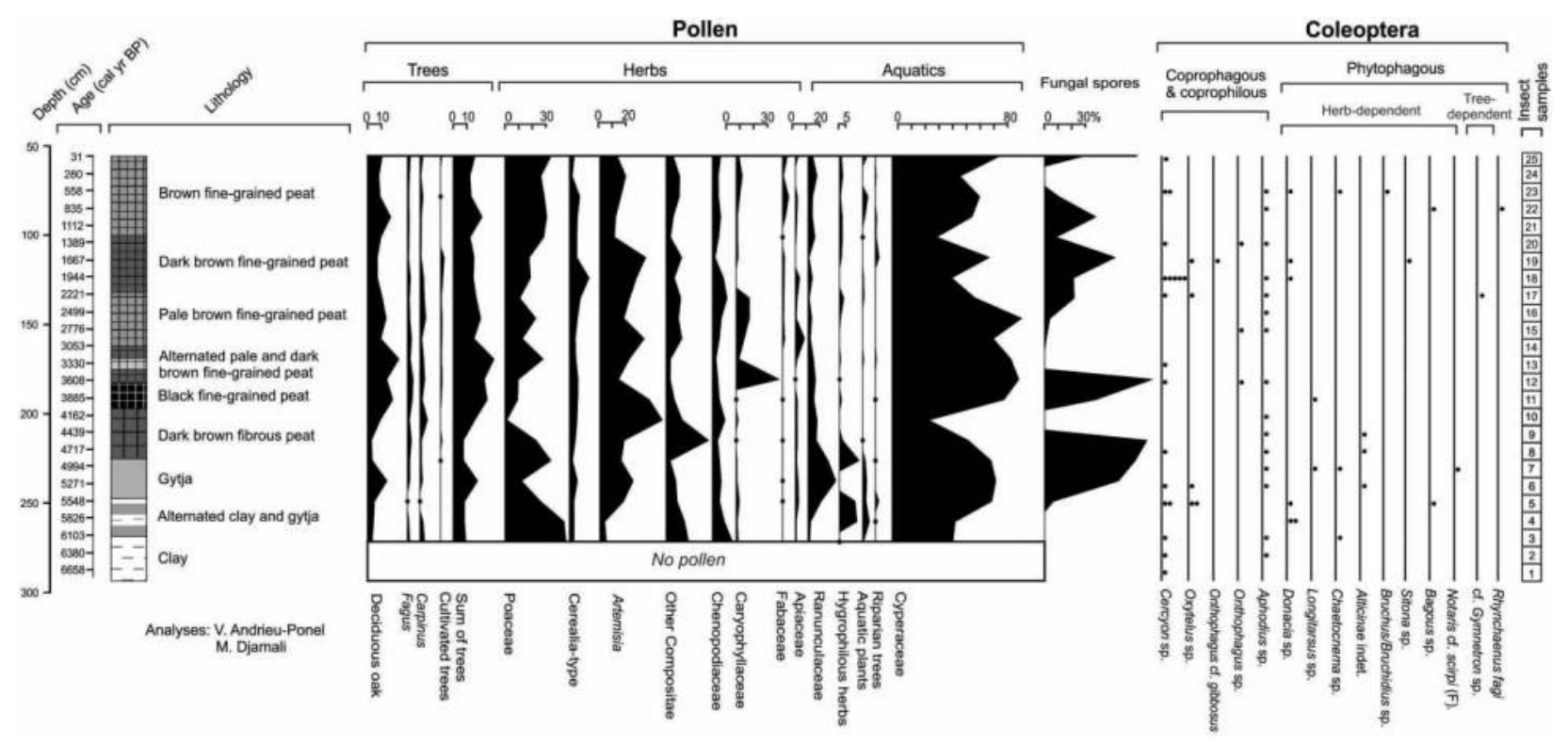

Figure 3 Pollen percentage diagram and insect frequency diagram from Lake Neor.

hygrophilous plants during the lacustrine stage (between ca. 6100 cal BP/4150 BC and 4700 cal $\mathrm{BP} / 2750 \mathrm{BC}$ ) and their decline upwards (but not disappearance) indicates that water holes could persist when the Cyperaceae peat bog expanded.

\section{Coleoptera}

A total of 63 taxa of Coleoptera (beetles) were identified in the sedimentary sequence (Table 2). Other orders are Heteroptera, with three taxa, and Hymenoptera, represented by unidentified ant fragments (Formicidae). Beetle fragments are present throughout the sequence but there is a clear impoverishment of the assemblages in the middle part of the sequence, and no insects were recovered from sample 14. This could be attributed to a change in taphonomic conditions. Most of the taxa identified in the sedimentary sequence are present today in Iran (Löbl and Smetana 2003-2010). The ecological requirements of beetles contained in fossil assemblages are diverse, including hygrophilous, aquatic, coprophagous/ coprophilous, herb-dependent and tree-dependent Coleoptera. Only the three last categories will be included in the synthetic diagram (Fig. 3) and discussed here.

Two important genera of coprophagous Coleoptera are present throughout the sequence, Onthophagus and Aphodius. At Neor, Aphodius is present in almost every beetle assemblage, whereas Onthophagus is less frequent. Both taxa feed on dung deposited by big mammals. The adults of Onthophagus lay eggs in burrows excavated in the substratum below the dung, whereas Aphodius species live during larval and adult stages inside the mass of excrement itself. Both genera are represented by hundreds of species in the Palaearctic region. Cercyon is a Hydrophilidae genus mainly associated with dung and decaying plant debris. Another beetle category associated with dung are the coprophilous insect genera Oxytelus and Platysthetus that prey upon small Arthropods such as Diptera larvae and mites that in turn feed on excrement.

Herb-dependent Coleoptera belong to three main families: Chrysomelidae, Bruchidae and Curculionidae. Donacia is a leaf beetle genus including about 22 West Palaearctic species, all of them associated with aquatic or helophytic plants. The flea beetles Longitarsus and Chaetocnema belong to two large genera that include hundreds of monophagous or oligophagous insects, associated with a wide variety of herbaceous plants. Bruchus/Bruchidius are almost exclusively dependent on Fabaceae, and develop inside the seeds during the larval stages. The weevil genus Sitona is also associated with Fabaceae and feeds on leaves and stems both adult and larva. Two other weevil taxa are associated with aquatic or helophytic plants: Bagous is a truly aquatic genus that feeds on Potamogeton, Utricularia, Ceratophyllum, Stratiotes, Callitriche, according to the species, and Notaris cf. scirpi that lives on Carex.

Tree-dependent Coleoptera are represented by a unique specimen that occurs in sample 22 only. This insect is Rhynchaenus fagi; as suggested by its name, this minute weevil is mainly associated with Fagus (Hoffmann 1958), although it is also recorded on some other broadleaved trees. This is a widespread species occurring in most of the Palaearctic region.

\section{Discussion}

The importance of herb-dependent taxa, along with the almost complete absence of tree-dependent taxa suggests that the environment was open throughout 
Table 2 Coleoptera from Lake Neor

\begin{tabular}{|c|c|c|c|c|c|c|c|c|c|c|c|c|c|c|c|c|c|c|c|c|c|c|c|c|c|}
\hline Sample number & 1 & 2 & 3 & 4 & 5 & 6 & 7 & 8 & 9 & 10 & 11 & 12 & 13 & 14 & 15 & 16 & 17 & 18 & 19 & 20 & 21 & 22 & 23 & 24 & 25 \\
\hline Sample depth & $\begin{array}{l}\text { ठ্ల } \\
\text { 1 } \\
\text { ᄋ్స } \\
\end{array}$ &  & 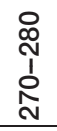 & $\begin{array}{l}\text { O } \\
\text { N } \\
\text { o } \\
\text { d }\end{array}$ & 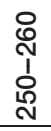 & 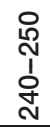 & $\begin{array}{l}\stackrel{ }{N} \\
\text { İ } \\
\text { N̦ }\end{array}$ & 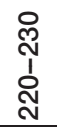 & $\begin{array}{l}\text { N } \\
\text { I } \\
\text { 은 } \\
\text { ․ }\end{array}$ & 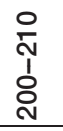 & 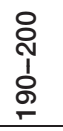 & 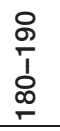 & 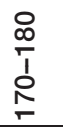 & \begin{tabular}{l}
2 \\
\hdashline \\
\\
0 \\
\hdashline
\end{tabular} & $\begin{array}{l}8 \\
\stackrel{0}{1} \\
1 \\
\stackrel{0}{1} \\
\end{array}$ & 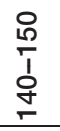 & $\begin{array}{l}\stackrel{o}{T} \\
\overline{1} \\
\stackrel{9}{\leftarrow} \\
\end{array}$ & 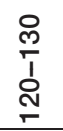 & 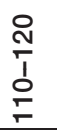 & $\begin{array}{l}\circ \\
\frac{1}{1} \\
8 \\
\end{array}$ & $\begin{array}{l}8 \\
\frac{1}{1} \\
8\end{array}$ & $\begin{array}{l}8 \\
\$ \\
1 \\
\infty \\
\end{array}$ & $\begin{array}{l}0 \\
\infty \\
1 \\
1\end{array}$ & $\begin{array}{l}0 \\
1 \\
8 \\
\end{array}$ & $\begin{array}{l}8 \\
1 \\
1 \\
\text { Nิ } \\
\end{array}$ \\
\hline \multicolumn{26}{|l|}{ Coleoptera } \\
\hline \multicolumn{26}{|l|}{ Carabidae } \\
\hline Notiophilus sp. & - & - & - & - & - & - & 1 & - & - & - & - & - & - & - & - & - & - & - & - & - & - & - & - & - & - \\
\hline Elaphrus cf. riparius L. & - & - & - & - & - & - & - & - & - & - & - & - & - & - & - & - & - & - & - & - & - & - & - & - & 1 \\
\hline Dyschirius sp. & - & - & - & - & - & - & - & - & - & - & - & - & - & - & - & - & - & - & - & - & - & 1 & - & - & - \\
\hline Bembidion cf. quadripustulatum Serv. & - & - & - & - & - & - & - & - & 1 & - & - & - & - & - & - & - & - & - & - & - & - & - & - & - & - \\
\hline Bembidion sp. A & - & - & - & - & - & - & - & - & - & - & - & - & - & - & - & - & - & - & - & - & - & 1 & - & - & - \\
\hline Bembidion sp. B & - & - & - & - & - & - & - & - & - & - & - & - & - & - & - & - & - & - & - & - & 1 & - & - & - & - \\
\hline Bembidion sp. C & - & - & - & - & - & - & - & - & - & - & - & - & - & - & - & - & - & - & 1 & - & - & - & - & - & - \\
\hline Bembidion sp. D & - & - & - & - & - & - & 1 & - & - & - & - & - & - & - & - & - & - & - & - & - & - & - & - & - & - \\
\hline Bembidion spp. & - & - & - & - & 1 & 2 & - & - & - & - & - & - & - & - & - & - & - & - & - & - & - & - & - & - & - \\
\hline Carabidae indet. & - & - & - & - & - & - & - & - & - & - & - & 1 & 1 & - & - & 1 & - & - & - & 1 & - & - & - & - & - \\
\hline Agonum (Europhilus) sp. & - & - & - & - & - & 1 & - & 2 & 3 & - & 1 & - & - & - & - & - & - & - & - & - & - & - & - & - & - \\
\hline Dytiscidae & & & & & & & & & & & & & & & & & & & & & & & & & \\
\hline Hygrotus inaequalis (F.) & - & - & - & - & - & - & 1 & 1 & - & - & 2 & - & - & - & - & - & - & - & - & - & - & - & - & - & - \\
\hline Noterus sp. & - & - & - & - & - & 1 & 1 & - & - & - & - & - & - & - & - & - & - & - & - & - & - & - & - & - & - \\
\hline Cf. Agabus sp. & - & - & - & - & - & - & 1 & - & - & - & - & - & - & - & - & - & - & - & - & - & - & - & - & - & - \\
\hline Cf. Rhanthus sp. & - & - & - & - & - & - & - & - & - & - & - & - & - & - & - & - & - & - & - & - & - & 1 & - & - & - \\
\hline Dytiscidae indet. & - & - & - & - & - & - & - & - & - & - & - & - & - & - & 2 & - & - & - & 1 & 1 & - & - & 3 & - & - \\
\hline \multicolumn{26}{|l|}{ Hydraenidae } \\
\hline Ochthebius cf. minimus & - & - & 1 & - & 1 & 1 & 1 & - & 5 & 5 & 2 & - & 1 & - & - & - & - & - & 1 & 2 & 3 & 1 & 1 & - & - \\
\hline Helophorus spp. & - & - & 1 & 1 & 2 & 1 & 1 & - & 1 & - & 1 & 1 & - & - & - & 1 & - & - & 3 & - & 1 & - & 2 & - & - \\
\hline \multicolumn{26}{|l|}{ Hydrophilidae } \\
\hline Cercyon sp. & 1 & 1 & 1 & - & 2 & 1 & - & 1 & - & - & - & 1 & 1 & - & - & - & 1 & 5 & - & 1 & - & - & 2 & - & 1 \\
\hline Laccobius sp. & - & 1 & - & - & 1 & - & - & - & - & - & - & - & - & - & - & - & - & - & - & - & - & - & - & - & - \\
\hline Enochrus spp. & - & - & - & 1 & 2 & 1 & 1 & - & - & - & - & 1 & - & - & - & - & 1 & - & - & 4 & 1 & 1 & 1 & 2 & - \\
\hline Hydrophilidae indet. & - & - & - & - & 1 & - & 1 & - & - & - & - & - & - & - & - & - & - & - & - & - & - & - & - & - & - \\
\hline \multicolumn{26}{|l|}{ Ptiliidae } \\
\hline $\begin{array}{l}\text { Acrotrichis sp. } \\
\text { Staphylinidae }\end{array}$ & - & - & - & - & - & - & - & 1 & 2 & - & - & - & - & - & - & - & - & - & - & - & - & - & 1 & - & - \\
\hline Eucnecosum brachypterum (Grav) & - & - & - & - & - & - & 1 & - & - & 2 & 6 & 3 & - & - & - & - & - & - & 1 & - & 1 & 2 & - & - & - \\
\hline Omaliinae indet. & - & - & - & - & - & - & - & - & - & - & - & - & 1 & - & - & - & - & - & - & - & - & - & - & - & - \\
\hline Oxytelus spp. & - & - & - & - & 2 & 1 & - & - & - & - & - & - & - & - & - & - & 1 & - & - & - & - & - & - & - & - \\
\hline Platysthetus cf. cornutus (Grav.) & - & 1 & 1 & - & - & - & 1 & 1 & - & - & - & - & - & - & - & - & - & - & 1 & - & 1 & - & 1 & 1 & - \\
\hline Platysthetus cf. nodifrons Mannh. & - & - & 1 & - & - & - & - & - & - & - & - & - & - & - & - & - & - & - & - & - & - & - & 1 & 1 & - \\
\hline Bledius sp. & - & - & - & - & - & 1 & - & - & - & - & - & - & - & - & - & - & - & - & - & - & - & - & - & - & - \\
\hline Stenus spp. & - & - & - & 1 & 2 & - & - & 1 & - & - & - & 1 & - & - & - & - & - & - & - & 1 & - & - & - & - & - \\
\hline Quedius/Philonthus spp. & - & - & - & - & 1 & 1 & 1 & - & - & - & - & - & - & - & - & - & - & - & 2 & - & - & - & - & 1 & - \\
\hline Tachyporus sp. & - & - & - & - & - & - & 1 & - & - & - & - & - & - & - & - & - & - & - & - & - & - & - & - & - & - \\
\hline Tachinus sp. & - & - & - & - & - & - & - & - & - & - & - & - & - & - & - & - & - & - & - & - & 1 & - & - & - & - \\
\hline Aleocharinae indet. & - & 1 & - & - & 1 & 2 & 1 & 4 & 16 & 11 & 12 & 4 & - & - & - & - & - & - & 2 & 1 & 2 & 1 & - & 1 & - \\
\hline Staphylinidae indet. & - & - & - & - & - & - & - & - & - & - & - & 2 & - & - & - & - & - & - & - & - & - & - & - & - & - \\
\hline
\end{tabular}


Elateridae

Elateridae indet

Helodidae

Helodidae indet.

Dryopidae

Dryops sp.

Heteroceridae

Heterocerus sp

Cucujidae

Airaphilus sp.

Cryptophagidae

Cf. Atomaria spp.

Cryptophagus sp

Phalacridae

Phalacridae indet

Lathridiidae

Corticariini in

Coccinellidae

Coccidula rufa (Hbst.)

Coccinellidae indet.

Anthicidae

Anthicus sp.

Tenebrionidae

$$
\text { Opatrinae indet. }
$$

Scarabaeidae

Onthophagus cf. gibbosus (Scriba)

Onthophagus sp.

Aphodius spp.

Chrysomelidae

Donacia sp.

Chaetocnema sp.

Alticinae indet.

Bruchidae

Bruchus/Bruchidius sp.

Curculionidae

Sitona sp.

Bagous sp.

Notaris cf. scirpi (F.)

Cf. Gymnetron sp.

Rhynchaenus fagi (L.)

Curculionidae indet.

Hemiptera

Hebrus sp.

Saldidae indet.

Hemiptera indet.

Hymenoptera

Formicidae indet 
the sequence, probably similar to the modern landscape on the Neor Plateau. The isolated occurrence of one specimen of a Fagus-associated weevil (Rhynchaenus fagi) may result from distant transport by wind; however, Fagus was certainly present in the Talesh mountains at this time, probably at lower altitude, on the slopes facing the Caspian Sea (Assadollahi 1980).

Coprophagous and coprophilous Coleoptera are present in every beetle assemblage from the bottom to the top of the sedimentary sequence. They suggest that dung was present throughout the sequence, and indicate the regular presence of medium and large size herbivores, wild and/or domestic. It is impossible to distinguish coprophagous/coprophilous Coleoptera associated with livestock, from Coleoptera associated with wild herbivores, but pollen data support a strong and early human impact expressed by the continuous presence of the pollen of Cerealia, arable weeds and ruderals.

From an archaeological point of view, the radiocarbon dates associated with these organic remains (quoted above) are culturally between the late Neolithic and Chalcolithic periods. The region of Talysh has a very rich archaeological record especially for the Bronze Age and Iron Age periods which was first recognised in the 19th century by Jacques de Morgan, a French scientist and prehistorian who worked in western Iran and later by other archaeologists (Khalatbari 2004; Tadahiko et al. 2003, 2004a, 2004b, 2005). These data, together with recent archaeological investigations, indicate that the region was occupied from the Lower Palaeolithic (Biglari et al. 2004). The discovery of a Late Neolithic site interpreted as a seasonal campsite (Nokandeh 2005; Ghasidian 2005), allows us to hypothesise possible transhumance during this period. The earliest domestication evidence of goats in the adjacent areas, namely the Zagros mountain range, is known to be around the 10000 BP (Zeder and Hesse 2000). Closer to the Talysh region, in the Qazvin plain, sheep and goat were already domesticated during the seventh millennium BP (Mashkour et al. 1999; Mashkour 2002). In all these regions, the exploitation of upland zones in summer, and lowlands or plains during the winter must have been a necessity for early populations in search for pasture (Bocherens et al. 2001; Mashkour et al. 2005).

The study of the animal bones from an Iron Age site in Talysh suggests the possibility of mobile pastoralism (Mashkour 2005). The ethnographic study by Marcel Bazin during the 70 s provides a precious and very detailed description of land use in Talysh (Bazin 1980, 9-45) and especially the use of different altitudes on the mountain in different periods of the year for herding sheep/goat and cattle. He divides the mountain into three ecological zones: the inferior level of the mountain (below $800 \mathrm{~m}$ ), the medium mountain (from 800 to $1400 \mathrm{~m}$ ), finally the "Alpages" (higher than $1400 \mathrm{~m}$ and extending up to $3000 \mathrm{~m}$ ). These high grass lands are exclusively used for sheep and goat herding. They are densely occupied seasonally by specialised herders. In another region of the Talysh, the Kaluraz valley, the same pattern of pastoral mobility is verified through a systematic survey of the present day distribution of the lowland and highland (Fahimi 2004; Kazua 2005; Kazua and Fahimi 2005). Bazin (1980) does not use the term "transhumance", but instead uses (in French) "migration pastorale". These are terms with precise ethnographic definitions. Here, we use "pastoral mobility" which is a general term referring to the fact that people had to move their herds for grass.

Lake Neor is located in the "Alpage" zone of summer pasture lands. Using these archaeological and ethnographic records it is plausible to envisage the high concentration of dung around the lake as an indicator of pastoral mobility, at least from the Late Neolithic to Late Chalcolithic/Early Bronze Age (end of the fifth millennium to the first quarter of third millennium) as indicated by the radiocarbon dates. This type of seasonal mobility has been also suggested for the adjacent areas, like the Zagros (Mashkour 2004; Mashkour and Abdi 2002; Mashkour et al. 2005).

In conclusion, both pollen and arthropod data are in agreement, indicating that during the last 6700 years at Neor, the landscape remained continuously open and subject to long-term impact by human groups. They show the early practice (at least from 6700 cal. BP) of cereal cultivation and later fruit tree cultivation (Cereals, Fabaceae, Prunus, Juglans and Olea).

\section{Acknowledgements}

This project was partly supported by Iranian National Institute for Oceanography (INIO), and especially its Director, Professor V. Chegini. We wish to thank Ms Tayebeh Akbarnia for providing us with several bibliographic references. M. Mashkour would like to thank Dr H. Fahimi for his comments on the archaeological part of the text

\section{References}

Assadollahi, F. 1980. Etude Phytosociologique des Forêts Hyrcaniennes - Essai Synthétique Application à la Région d'Assalem (Iran). Unpublished $\mathrm{PhD}$ thesis, University of Aix-Marseille III.

Bazin, M. 1980. Le Tâlech. Une Region Ethnique au Nord de l'Iran. Tome II (Recherches sur les civilisations. Synthèse $n^{\circ} 1$. Institut Français d'Iranologie de Téhéran. Bibliothèque iranienne). Paris: Editions ADPF

Beug, H. J. 2004. Leitfaden der Pollenbestimmung für Mitteleuropa und angrenzende Gebiete. München: Verlag Dr Friedrich Pfeil. 
Biglari, F., Heydari, S. and Shidrang, S. 2004. 5. Lower Paleolithic site of Ganj Par in the Gilan Province, Iran: a preliminary report, pp. 76-84 in Ohtsu, T., Nokandeh, J. and Kazuya, Y. (eds.), Preliminary Report of the Iran Japan Joint Archaeological Expedition to Gilan. Third Season. Tehran and Tokyo: Iranian Cultural Heritage and Tourism Organization \& Middle Eastern Culture Center in Japan.

Blaauw, M. 2010. Methods and code for "classical" age-modelling of radiocarbon sequences. Ouaternarv Geochronologv 5 , $512-518$.

Bocherens, H., Mashkour, M., Billiou, D., Pellé, E. and Mariotti, A. 2001. A new approach for studying prehistoric managements in arid areas: intra-tooth isotopic analyses of archaeological Caprine from Iran. Comptes-Rendus de l'Académie des Sciences. Série II, 332, 67-74.

Böhme, J. 2005. Die Käfer Mitteleuropas. Band K: Katalog (Faunistische Übersicht). 2. Auflage. München: Springer.

Coope, G. R. 1986. Coleoptera analysis, pp. 703-713 in Berglund, B. E. (ed.), Handbook of Holocene Palaeoecology and Palaeohydrology. Chichester: Wiley \& Sons.

Djamali, M. 2008. Changements Paléoenvironnementaux en Iran au Cours des deux Derniers Cycles Climatiques (VégétationClimat-Anthropisation). Unpublished $\mathrm{PhD}$ thesis, Université Paul Cézanne, Marseille.

Djamali, M., de Beaulieu, J.-L., Campagne, P., Akhani, H., Andrieu-Ponel, V., Ponel, P. and Leroy, S. 2009a. Modern pollen rain-vegetation relationships along a forest steppe transect in the Golestan National Park, NE Iran. Review of Palaeobotanv and Palvnologv 153, 272-281.

Djamali, M., de Beaulieu, J.-L., Miller, N. F., Andrieu-Ponel, V., Berberian, M., Gandouin, E., Lahijani, H., Ponel, P., Salimian, M. and Guiter, F. 2009b. A late Holocene pollen record from Lake Almalou in NW Iran: evidence for changing land-use in relation to some historical events during the last 3700 years. Journal of Archaeological Science 36, 1346-1375.

Djamali, M., de Beaulieu, J.-L., Miller, N. F., Andrieu-Ponel, V., Ponel, P., Lak, R., Sadeddin, M., Akhani, H. and Fazeli, H. 2008. Vegetation history of the SE section of Zagros Mountains during the last five millennia; a pollen record from the Maharlou Lake, Fars Province, Iran. Vegetation Historv and Archaeobotany 18, 123-136.

Fahimi, H. 2004. II.1. Outline of the second season of the general survey on the West Bank of the Sefidrud, pp. 11-13 in Tadahiko, O., Nokandeh, J. and Kazuya, Y. (eds.), Preliminary Report of the Iran Japan Joint Archaeological Expedition to Gilan, Second Season, 2002. Tehran and Tokyo Iranian Cultural Heritage and Tourism Organization \& Middle Eastern Culture Center in Japan.

Ghasidian, E. 2005. A preliminary report on the stone artifacts of Arg-e Dasht, pp. 57-60 in Tadahiko, O., Nokandeh, J. and Kazuya, Y. (eds.), Preliminary Report of the Iran Japan Joint Archaeological Expedition to Gilan, Fourth Season. Tehran and Tokyo: Iranian Cultural Heritage and Tourism Organization \& Middle Eastern Culture Centre in Japan.

Hoffmann, A. 1958. Coléoptères Curculionides, troisième partie. Faune de France 62. Paris: Fédération Française des Sociétés de Sciences Naturelles.

Kazua, Y. 2005. IV. Formation of Historical and Cultural Landscape of the Kaluraz Valley, pp. 109-113 in Tadahiko, O., Nokandeh, J. and Kazuya, Y. (eds.), Preliminary Report of the Iran Japan Joint Archaeological Expedition to Gilan, Third Season. Tehran and Tokyo: Iranian Cultural Heritage and Tourism Organization \& Middle Eastern Culture Center in Japan.

Kazua, Y. and Fahimi, H. 2005. II.1. General survey. The fourth season of Archaeological Survey in the West Bank of the Sefidrud (from the Sorkhan Valley to the River Qezl-Owzan), pp. 7-10 in Tadahiko, O., Nokandeh, J. and Kazuya, Y. (eds.), Preliminary Report of the Iran Japan Joint Archaeological Expedition to Gilan, Fourth Season. Tehran and Tokyo: Iranian Cultural Heritage and Tourism Organization \& Middle Eastern Culture Center in Japan.

Khalatbari, M. R. 2004. Archaeological Investigations in Talesh Gilan. Tehran: General Office of Iranian Cultural Heritage Organization of Gilan, Archaeological Research Center.

Koch, K. 1989a. Die Käfer Mitteleuropas, Ökologie 1. Krefeld: Goecke and Evers.

Koch, K. 1989b. Die Käfer Mitteleuropas, Ökologie 2. Krefeld: Goecke and Evers.

Koch, K. 1992. Die Käfer Mitteleuropas, Ökologie 3. Krefeld: Goecke and Evers.
Löbl, I. and Smetana, A. (eds.). 2003-2010. Catalogue of Palaearctic Coleoptera. Stenstrup: Apollo Books.

Mashkour, M. 2002. Chasse et élevage au Nord du Plateau central iranien entre le Néolithique et l'Âge du Fer. Paléorient 28, $27-42$.

Mashkour, M. 2004. Tracing ancient 'Nomads': isotopic research on the origins of vertical 'transhumance' in the Zagros region. Nomadic People 7, 36-47.

Mashkour, M. 2005. Animal exploitation of the lowland pastures of Guilan (Iran) during the Iron Age. A preliminary archaeozoological study of Jalaliyeh Kaluraz, pp. 96-108 in Tadahiko, O., Nokandeh, J. and Kazuya, Y. (eds.), Preliminary Report of the Iran Japan Joint Archaeological Expedition to Gilan, Fourth Season. Tehran and Tokyo: Iranian Cultural Heritage and Tourism Organization \& Middle Eastern Culture Centre in Japan.

Mashkour, M. and Abdi, K. 2002. The question of mobile pastoralist campsites in archaeology: the case of Tuwah Khoshkeh, pp. 211-227 in Buitenhuis, H., Choyke, A. M., Mashkour, M. and Al Shyab, A. H. (eds.), Archaeozoology of the Near East V. Groeningen: ARC Publications 62.

Mashkour, M., Bocherens, H. and Moussa, I. 2005. Long distance movement of sheep and goats of Bakhtari nomads tracked with intra-tooth variations of stable isotopes (13C and 18O), pp. 113-124 in Davies, J., Fabis, M., Mainland, I., Richards, M. and Thomas, R. (eds.), Diet and Health in Past Animal Populations: Current Research and Future Directions. Oxford: Oxbow.

Mashkour, M., Fontugne, M. and Hatté, C. 1999. Investigations on the evolution of subsistence economy in the Qazvin Plain (Iran) from the Neolithic to the Iron Age. Antiquity 73, 65-76.

Miehe, G., Miehe, S., Kaiser, K., Reudenbach, C., Behrendes, L., Duo, L. and Schlütz, F. 2009. How old is pastoralism in Tibet? An ecological approach to the making of a Tibetan landscape. Palaeogeographv Palaeoclimatology Palaeoecologv 276, 130-147.

Moore, P. D., Webb, J. A. and Collinson, M. E. 1994. Pollen Analysis, 2nd ed. Oxford: Blackwell Scientific Publications.

Neumann, F., Schölzel, C., Litt, T., Hense, A. and Stein, M. 2007. Holocene vegetation and climate history of the northern Golan heights (Near East). Vegetation Historv and Archaeobotanv 16, 329-346.

Nejadsattari, T. 1978. An Ecological and Systematic Study of Phytoplankton and Epiphytic Algae of Neur Lake, Iran. Unpublished MSc thesis. University of Tehran [In Persian with an English abstract].

Nokandeh, J. 2005. Arg-e Dasht, the first Neolithic discovered region in Gilan Province, pp. 50-56 in Tadahiko, O., Nokandeh, J. and Kazuya, Y. (eds.), Preliminary Report of the Iran Japan Joint Archaeological Expedition to Gilan, Fourth Season. Tehran and Tokyo: Iranian Cultural Heritage and Tourism Organization \& Middle Eastern Culture Centre in Japan.

Ramezani, E., Joosten, H., Marvie Mohadjer, R., Knapp, H.-D. and Ahmadi, H. 2008. The late-Holocene vegetation history of the Central Caspian (Hyrcanian) forests of northern Iran. The Holocene 18, 305-319.

R Development Core Team. 2010. R: A Language and Environment for Statistical Computing. Vienna, Austria: R Foundation for Statistical Computing,. ISBN 3-900051-07-0. http://www. R-project.org [last accessed 01.02.2010].

Reille, M. 1992. Pollen et Spores d'Europe et d'Afrique du Nord. Marseille: Laboratoire de Botanique Historique et Palynologie.

Reille, M. 1995. Pollen et Spores d'Europe et d'Afrique du Nord, Supplément 1. Marseille: Laboratoire de Botanique Historique et Palynologie.

Reille, M. 1998. Pollen et Spores d'Europe et d'Afrique du Nord, Supplément 2. Marseille: Laboratoire de Botanique Historique et Palynologie.

Sharifi, J. 2009. Vegetation Types of Ardebil and Astara Region. Tehran: Research Institute of Forests and Rangelands, Iranian Ministry of Agriculture [In Persian].

Stuiver, M., Reimer, P. J., Bard, E., Beck, J. W., Burr, G. S., Hughen, K. A., Kromer, B., McCormac, G., van der Plicht, J. and Spurk, M. 1998. INTCAL98 radiocarbon age calibration 24,000-0 cal BP. Radiocarbon 40, 1041-1084.

Tadahiko, O., Nokandeh, J. and Kazuya, Y. 2003, Preliminary Report of the Iran Japan Joint Archaeological Expedition to Gilan, First Season, 2001. Tehran and Tokyo: Iranian Cultural Heritage and Tourism Organization \& Middle Eastern Culture Center in Japan. 
Tadahiko, O., Nokandeh, J. and Kazuya, Y. 2004a. Preliminary Report of the Iran Japan Joint Archaeological Expedition to Gilan, Second Season. Tehran and Tokyo: Iranian Cultural Heritage and Tourism Organization \& Middle Eastern Culture Center in Japan.

Tadahiko, O., Nokandeh, J. and Kazuya, Y. 2004b. Preliminary Report of the Iran Japan Joint Archaeological Expedition to Gilan, Third Season. Tehran and Tokyo: Iranian Cultural Heritage and Tourism Organization \& Middle Eastern Culture Center in Japan.
Tadahiko, O., Nokandeh, J. and Kazuya, Y. 2005. Preliminary Report of the Iran Japan Joint Archaeological Expedition to Gilan, Fourth Season. Tehran and Tokyo: Iranian Cultural Heritage and Tourism Organization \& Middle Eastern Culture Center in Japan.

van Zeist, W. and Bottema, S. 1977. Palynological investigations in western Iran. Palaeohistoria 19, 19-85.

Zeder, M. A. and Hesse, B. 2000. The initial domestication of goats (Capra hircus) in the Zagros mountains 10,000 years ago. Science 287, 2254-2257. 